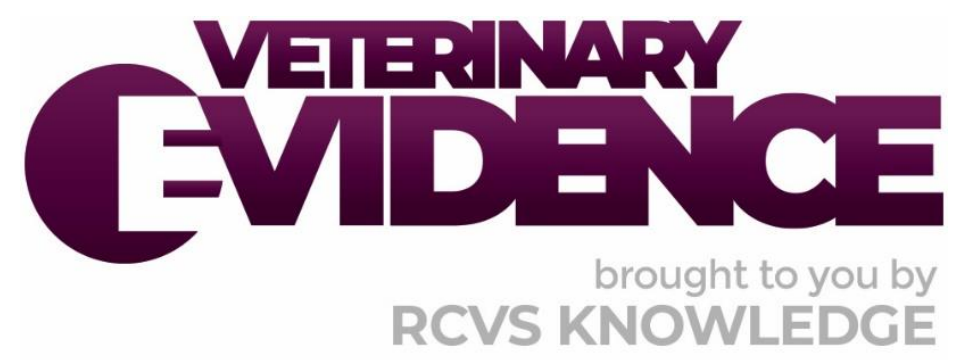

\title{
Comparison of the safety of alfaxalone and propofol as anaesthetic induction agents in bitches undergoing c-section
}

\author{
A Knowledge Summary by
}

Ben Haythornthwaite $\mathrm{BA}^{1^{*}}$

${ }^{1}$ Cambridge University Veterinary School, Madingley Rd, Cambridge CB3 OES
${ }^{*}$ Corresponding Author (bhaythornthwaite@hotmail.co.uk)

ISSN: 2396-9776

Published: 19 Aug 2020

in: Vol 5, Issue 3

DOI: $10.18849 /$ VE.V5I3.313

Reviewed by: Jane Alexander (BVetMed, CertVA, MRCVS) and Myra Forster-van Hijfte (CertVR CertSAM DipECVIM-cA FRCVS)

Next Review Date: 15 Nov 2021 


\section{KNOWLEDGE SUMMARY}

\section{PICO question}

In bitches and their puppies undergoing caesarean section, is an alfaxalone or a propofol induction safer?

\section{Clinical bottom line}

\section{Category of research question}

Risk

\section{The number and type of study designs reviewed}

Six papers were critically reviewed. There were two randomised controlled trials directly comparing alfaxalone and propofol inductions, two randomised controlled trials including a propofol induction in one of the experimental groups and two non-comparative studies.

\section{Strength of evidence}

\section{Moderate}

\section{Outcomes reported}

Propofol and alfaxalone can both be used safely for the anaesthesia of bitches and their puppies undergoing caesarean section. There is evidence that alfaxalone may provide better anaesthesia quality for the bitches, and the puppies may be delivered with higher indicators of puppy vitality following its use. Further research into the beneficial clinical outcomes of alfaxalone should be investigated.

\section{Conclusion}

The use of both propofol and alfaxalone for the induction of bitches undergoing caesarean section can be recommended.

\section{How to apply this evidence in practice}

The application of evidence into practice should take into account multiple factors, not limited to: individual clinical expertise, patient's circumstances and owners' values, country, location or clinic where you work, the individual case in front of you, the availability of therapies and resources.

Knowledge Summaries are a resource to help reinforce or inform decision-making. They do not override the responsibility or judgement of the practitioner to do what is best for the animal in their care. 


\section{Clinical Scenario}

For canines undergoing a caesarean section, anaesthesia can be a risk to both the bitch and the puppies. Silva et al. (2009) recorded significantly lower Apgar scores for puppies born from caesarean section, for which anaesthesia may be partially responsible. Supporting this, Luna et al. (2004) found that multiple anaesthetic protocols have profound effects on neonatal neurological function postpartum due to passage of anaesthetic agents across the placenta following administration. Propofol in particular has been found to rapidly cross the placenta into the foetal circulation (Sánchez-Alcaraz, 1998). In a study by Moon et al. (1998), 58\% of caesarean sections were carried out on an emergency basis. This highlights the importance of having a safe anaesthetic protocol in place for swift treatment of patients who may already be compromised. Propofol is frequently used as an induction agent in caesarean sections and alfaxalone is becoming more commonly used in the anaesthesia of pregnant bitches. This review aims to compare the safety of these two induction agents, both in the bitches and the puppies.

\section{The evidence}

Six studies in total were found relevant to the PICO, including four randomised controlled trials (Metcalfe et al., 2014; Doebeli et al., 2013; Vilar et al., 2018; and Luna et al., 2004) and two non-comparative studies (De Cramer et al., 2017; and Funkquist et al., 1997). One of the randomised controlled trials was blinded (Doebeli et al., 2013). The variables measured included puppy survival and vitality (Metcalfe et al., 2014; Doebeli et al., 2013; Vilar et al., 2018; Luna et al., 2004; De Cramer et al., 2017; and Funkquist et al., 1997) and anaesthetic variables in the bitch (Metcalfe et al., 2014; Doebeli et al., 2013; Vilar et al., 2018; De Cramer et al., 2017; and Funkquist et al., 1997). However, different measures of puppy vitality and anaesthetic variables in the bitches were recorded in each study.

Two of the studies directly compared the use of alfaxalone and propofol as induction agents (Metcalfe et al., 2014; Doebeli et al., 2013). These studies will be most useful when comparing the safety of the two drugs. The other studies (Vilar et al., 2018; Luna et al., 2004; De Cramer et al., 2017; Funkquist et al., 1997) included the use of propofol as an induction agent in one of their experimental groups. Although it will be useful to assess the safety of propofol in these studies to compare with the results found in the studies by Metcalfe et al. (2014) and Doebeli et al. (2013), they will not offer evidence of as high a quality as in the two comparative randomised controlled trials. Unfortunately as alfaxalone is only recently becoming more commonly used in caesarean sections, I found fewer studies including it in one of the experimental groups.

\section{Summary of the evidence}

\begin{tabular}{|c|c|}
\hline \multicolumn{2}{|l|}{ Metcalfe et al. (2014) } \\
\hline Population: & $\begin{array}{l}\text { Bitches undergoing caesarean section and the puppies born to them. } \\
\text { No exclusions were made for breed, parity, urgency or whether any } \\
\text { pups had been born naturally prior to presentation. The mean age for } \\
\text { alfaxalone group was } 48.9 \pm 21.4 \text { months. The mean age for the } \\
\text { propofol group was } 58.3 \pm 18.1 \text { months. }\end{array}$ \\
\hline Sample size: & 74 bitches \\
\hline Intervention details: & $\begin{array}{l}\text { Cases were randomised in blocks of three so that two in three would } \\
\text { receive alfaxalone induction and one in three would receive propofol } \\
\text { induction: } \\
\text { 1. Alfaxalone induction } n=48 / 74(65 \%) \\
\text { 2. Propofol induction } n=26 / 74(35 \%) \\
\text { Experimental details: } \\
\text { - Before anaesthesia was induced, the clinical status of each } \\
\text { patient was determined by physical examination. }\end{array}$ \\
\hline
\end{tabular}




\begin{tabular}{|c|c|}
\hline & 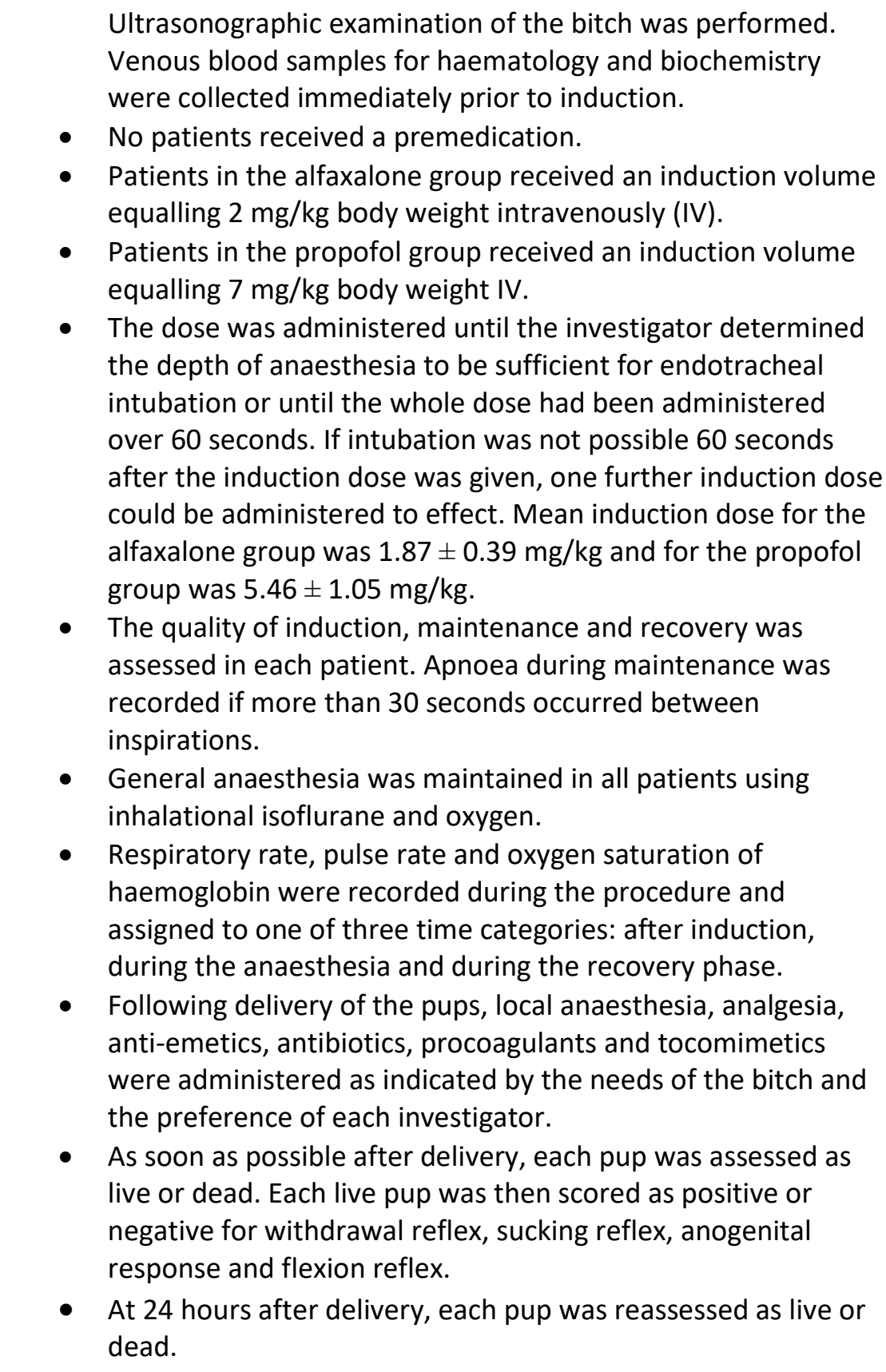 \\
\hline Study design: & Prospective, non-blinded, randomised, positive controlled trial \\
\hline Outcome studied: & $\begin{array}{l}\text { 1. Quality of anaesthetic induction, maintenance and recovery in } \\
\text { the subjects. This was measured as percentage of bitches in } \\
\text { which apnoea was recorded and by a subjective scoring system } \\
\text { as described by Ko et al. (1998). } \\
\text { 2. Puppy survival measured as percentage alive at birth and } 24 \\
\text { hours after. } \\
\text { 3. Puppy vigour measured by being scored as either positive or } \\
\text { negative for four health vigour assessments - withdrawal } \\
\text { reflex, sucking reflex, anogenital response and flexion reflex. }\end{array}$ \\
\hline $\begin{array}{l}\text { Main findings: } \\
\text { (relevant to PICO question): }\end{array}$ & $\begin{array}{l}\text { - Induction apnoea was recorded in } 7 / 48(15 \%) \text { bitches in the } \\
\text { alfaxalone group and } 6 / 26(25 \%) \text { bitches in the propofol group. } \\
\text { - Maintenance apnoea was recorded in } 2 / 48(4 \%) \text { bitches in the } \\
\text { alfaxalone group and } 4 / 26(17 \%) \text { bitches in the propofol group }\end{array}$ \\
\hline
\end{tabular}




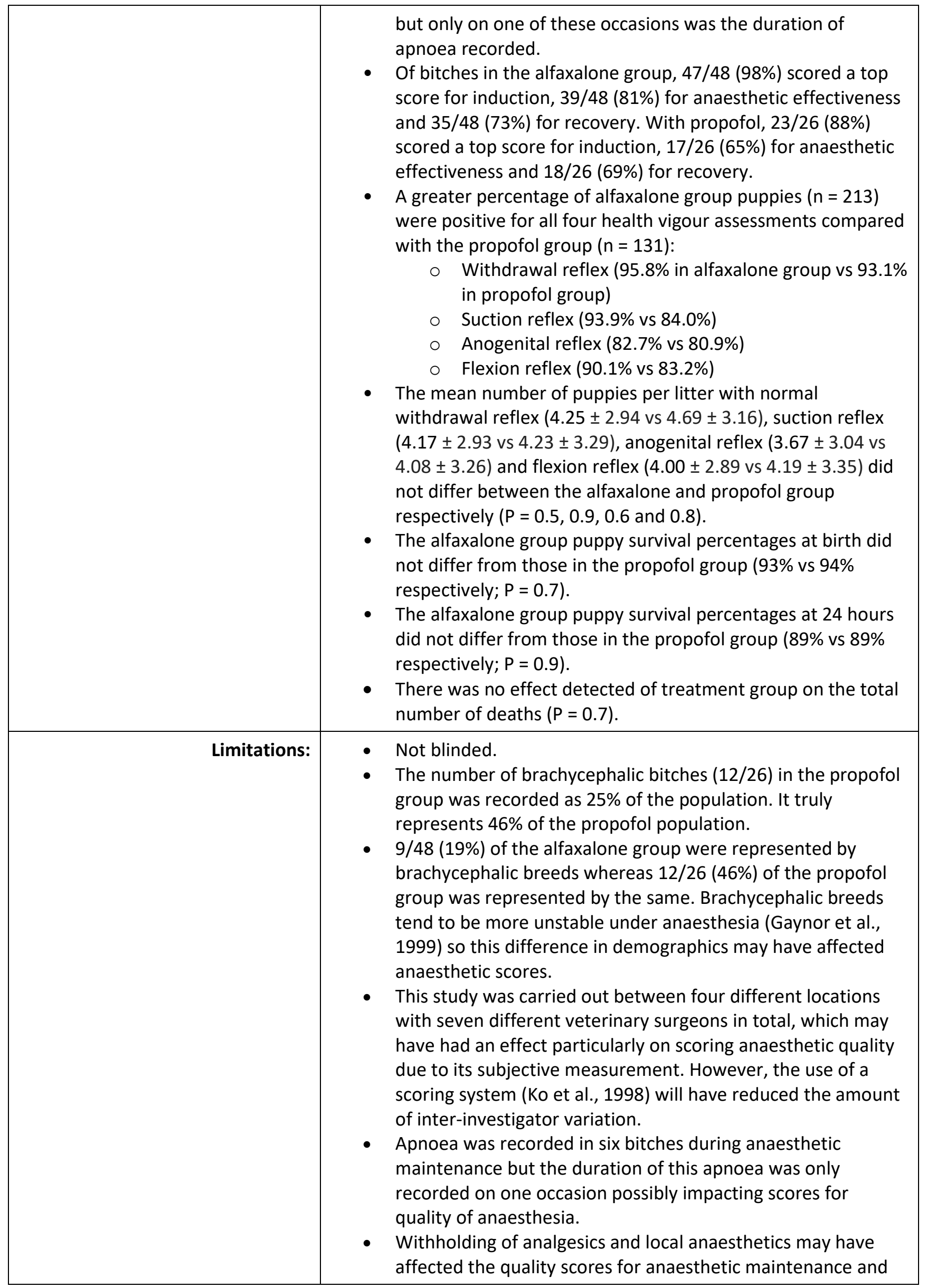




\begin{tabular}{|l|l|}
\hline & $\begin{array}{l}\text { recovery. } \\
\text { The propofol sample size was half the size of the alfaxalone } \\
\text { sample size. } \\
\text { No analysis of respiratory rates, pulse rates, oxygen } \\
\text { saturations and rectal temperatures. }\end{array}$ \\
\hline
\end{tabular}

\begin{tabular}{|c|c|}
\hline \multicolumn{2}{|l|}{ Doebeli et al. (2013) } \\
\hline Population: & $\begin{array}{l}\text { Bitches presenting with dystocia for which caesarean section was } \\
\text { indicated and the puppies born to them. Mean age of the bitches was } \\
3 \text { years, ranging from } 1 \text { to } 11 \text { years. Mean body weight of the bitches } \\
\text { was } 7.3 \mathrm{~kg} \text {, ranging from } 1.6 \text { to } 51 \mathrm{~kg} \text {. }\end{array}$ \\
\hline Sample size: & $\begin{array}{l}22 \text { bitches } \\
81 \text { puppies }\end{array}$ \\
\hline Intervention details: & $\begin{array}{l}\text { Cases divided in half between those receiving alfaxalone induction } \\
\text { and those receiving propofol induction: } \\
\text { 1. Alfaxalone group } \mathrm{n}=11 \text { ( } 50 \%) \\
\text { 2. Propofol group } \mathrm{n}=11 \text { ( } 50 \%) \\
\text { Experimental Details: } \\
\text { - All bitches received IV fluids (Lactated Ringer's solution, } 10- \\
20 \mathrm{~mL} / \mathrm{kg} / \mathrm{h} \text { ) immediately after presentation until after } \\
\text { recovery. In those bitches with poor general condition or } \\
\text { severe dehydration, HAES-steril } 10 \% \text { was added (1-2 } \\
\text { mL/kg/h). } \\
\text { Before induction, all bitches were preoxygenated for } 5 \\
\text { minutes using flow by oxygen at } 2 \mathrm{~L} / \text { minute and received a } 20 \\
\text { mg/kg IV dose of cefazolin. } \\
\text { - Bitches in the alfaxalone group received an induction volume } \\
\text { equaling } 1-2 \mathrm{mg} / \mathrm{kg} \text { body weight IV. } \\
\text { Bitches in the propofol group received an induction volume } \\
\text { equaling } 2-6 \mathrm{mg} / \mathrm{kg} \text { body weight IV. } \\
\text { - The surgeons and the observer who performed the } \\
\text { evaluations after anaesthesia induction were blind to the } \\
\text { agent used. } \\
\text { - Anaesthesia maintained using isoflurane to effect. } \\
\text { - Immediately after the last puppy was delivered, all bitches } \\
\text { were started on } 5 \text { mcg/kg/h continuous rate infusion of } \\
\text { fentanyl. } \\
\text { - All bitches received } 14 \text { mcg/kg buprenorphine and } 4 \text { mg/kg } \\
\text { carprofen IV } 20 \text { minutes before the end of surgery. } \\
\text { After delivery, all puppies had fluid cleared from the upper } \\
\text { airways using suctioning. They were actively warmed and } \\
\text { were oxygenated using flow by oxygen at } 2 \mathrm{~L} / \mathrm{m} \text {. If breathing } \\
\text { was inadequate, Respirot was given at a dose of } 1-2 \text { drops } \\
\text { orally and } 3-5 \mathrm{~mL} / 100 \mathrm{~g} 5 \% \text { glucose was given subcutaneously. } \\
\text { pupy was performed. }\end{array}$ \\
\hline Study design: & Prospective, blinded, randomised, positive controlled trial \\
\hline
\end{tabular}




\begin{tabular}{|c|c|}
\hline Outcome studied: & $\begin{array}{l}\text { 1. Neonatal viability determined using a modified Apgar score } \\
\text { developed by Veronesi et al. (2009) at 5, } 15 \text { and } 60 \text { minutes } \\
\text { after delivery. Heart rate, respiratory effort, reflex irritability, } \\
\text { motility and mucous membrane colour were rated } 0 \text { (absent), } \\
1 \text { (detectable, weak) or } 2 \text { (detectable, strong). } \\
\text { 2. Puppy survival measured as percentage alive at birth, } 60 \\
\text { minutes, } 24 \text { hours, } 3 \text { days and } 3 \text { months after. } \\
\text { 3. Pre and intra-operative parameters in bitches including } \\
\text { temperature, heart rate, respiratory rate, packed cell volume } \\
\text { (PCV), total protein, anaesthesia duration, mean blood } \\
\text { pressure and delivery time. }\end{array}$ \\
\hline $\begin{array}{l}\text { Main findings: } \\
\text { (relevant to PICO question): }\end{array}$ & $\begin{array}{l}\text { - Puppy survival did not differ between the alfaxalone and the } \\
\text { propofol group at any of the measured time intervals. } \\
\text { - } 4 \text { puppies from each group were born dead over the course of } \\
\text { the study. } \\
\text { - At the first assessment } 5 \text { minutes after birth, the proportion } \\
\text { of puppies in the alfaxalone group }(\mathrm{N}=36 \text { ) with high }(7-10) \text {, } \\
\text { medium }(4-6) \text { and low }(0-3) \text { Apgar scores were } 68 \%, 15 \% \text { and } \\
17 \% \text { respectively. The same proportions for the propofol } \\
\text { group ( } N=45 \text { ) were } 19 \%, 31 \% \text { and } 50 \% \text { respectively. } \\
\text { - The Apgar scores at } 5,15 \text { and } 60 \text { minutes after delivery were } \\
\text { greater in the alfaxalone group than in the propofol group. } \\
\text { The overall estimated score difference between the groups } \\
\text { was } 3.3(P<0.001) \text {. } \\
\text { Pre and intra-operative parameters did not differ between the } \\
\text { alfaxalone and the propofol group. Maternal recovery was } \\
\text { uneventful and rapid in both groups. }\end{array}$ \\
\hline Limitations: & $\begin{array}{l}\text { - A rather small sample size was used. Although a significant } \\
\text { difference in Apgar scores was found between the alfaxalone } \\
\text { and propofol groups, a larger population may provide better } \\
\text { information on the range of patients seen in practice. } \\
\text { - Ranges were given for alfaxalone and propofol induction dose } \\
\text { but no indication as to how doses were chosen. } \\
\text { - No indication as to how patients were distributed between } \\
\text { study groups. } \\
\text { - Although the authors report maternal recovery as uneventful } \\
\text { and rapid, no values are provided with regards to recovery } \\
\text { time. } \\
\text { The value of Apgar scores in predicting short-term survival of } \\
\text { puppies is not fully known. }\end{array}$ \\
\hline
\end{tabular}

Vilar et al. (2018)

\begin{tabular}{|r|l|}
\hline Population: & Bitches undergoing elective caesarean section. \\
\hline Sample size: & $\begin{array}{l}45 \text { bitches from four different breeds (French Bulldog, Yorkshire } \\
\text { Terrier, Chihuahua and Bull Terrier). }\end{array}$ \\
\hline Intervention details: & $\begin{array}{r}\text { Bitches assigned uniformly to three experimental groups: } \\
\text { 1. Group P: propofol induction and maintenance }(\mathrm{n}=17)\end{array}$ \\
\hline
\end{tabular}




\begin{tabular}{|c|c|}
\hline & $\begin{array}{l}\text { 2. Group PS: propofol induction, sevoflurane maintenance ( } \mathrm{n}= \\
\text { 14) } \\
\text { 3. Group PES: propofol induction and maintenance, lidocaine } \\
\text { epidural analgesia ( } \mathrm{n}=14 \text { ) } \\
\text { - All bitches premedicated with morphine ( } 0.2 \mathrm{mg} / \mathrm{kg} \text { ) ten } \\
\text { minutes before induction with } 3 \mathrm{mg} / \mathrm{kg} \text { propofol. } \\
\text { Bitches in group P were taken straight to surgery and } \\
\text { maintained on repeated boluses of propofol. Once the last } \\
\text { neonate was removed, maintenance was swapped to } \\
\text { sevoflurane (0-8\%) in oxygen. } \\
\text { Bitches in group PS were intubated following induction and } \\
\text { maintained on sevoflurane (0-8\%). } \\
\text { Bitches in group PES were intubated and then epidural } \\
\text { anaesthesia was performed using lidocaine ( } 2 \% \text { ) into the } \\
\text { lumbosacral intervertebral space. Once the last neonate was } \\
\text { removed, maintenance was swapped to sevoflurane (0-8\%) in } \\
\text { oxygen. } \\
\text { Intramuscular tramadol and postoperative oral amoxicillin } \\
\text { plus clavulanic acid was given to all patients. In all groups } 1-2 \\
\text { mcg/kg fentanyl IV was provided when required to manage } \\
\text { intraoperative pain. } \\
\text { Once the bitch was transferred to the surgical area, heart } \\
\text { rate, respiratory rate, oxygen saturation, rectal temperature } \\
\text { and blood pressure were monitored every } 5 \text { minutes. } \\
\text { At } 60 \text { and } 120 \text { minutes after surgery, it was assessed whether } \\
\text { the female was conscious, able to get up and/or walk and } \\
\text { accept the puppies. } \\
\text { Immediately following delivery, the puppies were evaluated } \\
\text { and Apgar scored using a modified Apgar score model (Batista } \\
\text { et al., } 2014 \text { ). Puppies with an Apgar score }<5 \text { were provided } \\
\text { with neonatal resuscitation protocols. } \\
\text { Puppies were classified as born dead, born alive but with } \\
\text { severe defects, born alive but dead within } 6 \mathrm{~h} \text { or viable and } \\
\text { still alive after } 6 \mathrm{~h} \text {. Neonatal viability was also assessed at } 12 \text {, } \\
24 \text { and } 48 \mathrm{~h} \text { after birth. }\end{array}$ \\
\hline Study design: & Non-blinded, randomised controlled trial \\
\hline Outcome studied: & $\begin{array}{l}\text { 1. Intra and postoperative parameters in bitches including heart } \\
\text { rate, respiratory rate, oxygen saturation, rectal temperature, } \\
\text { consciousness, ability to get up and/or walk and accept the } \\
\text { puppies. } \\
\text { 2. Anaesthetic variables in bitches including number of propofol } \\
\text { boluses required, time taken to start surgery following } \\
\text { intubation and sevoflurane concentration required intra- } \\
\text { operatively. } \\
\text { 3. Puppy survival measured as percentage alive at birth and } \\
\text { percentage mortality after } 12 \text { hours and } 48 \text { hours. } \\
\text { 4. Puppy vitality measured via a modified Apgar scoring system } \\
\text { (Batista et al., 2014) at birth and } 60 \text { minutes after. Numbers of } \\
\text { neonates requiring neonatal resuscitation was also recorded. }\end{array}$ \\
\hline
\end{tabular}




\begin{tabular}{|c|c|}
\hline $\begin{array}{l}\text { Main findings: } \\
\text { (relevant to PICO question): }\end{array}$ & 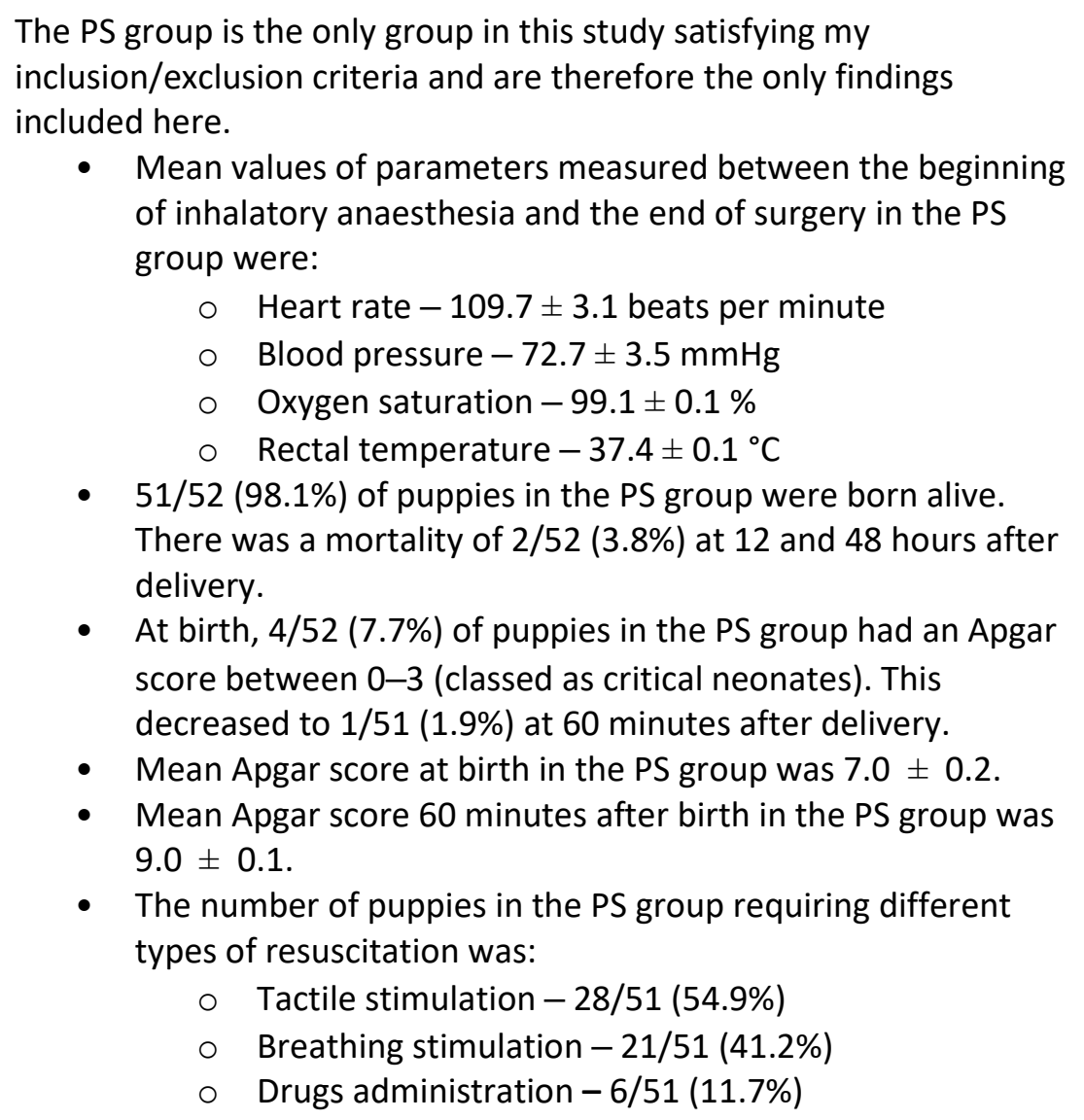 \\
\hline Limitations: & $\begin{array}{l}\text { - } \quad \text { Not blinded. } \\
\text { - } \text { purposison of this review. } \\
\text { Bitches were premedicated with morphine which may have } \\
\text { affected puppy vitality. } \\
\text { - Brachycephalics were heavily represented, however this may } \\
\text { correlate with the relevant clinical population. } \\
\text { - A scoring system for the quality of anaesthesia experienced by } \\
\text { the bitches may have been useful, for example that described } \\
\text { by Ko et al. (1998). } \\
\text { Results were not provided for some of the parameters } \\
\text { measured in the bitches - consciousness, ability to get up } \\
\text { and/or walk and accept the puppies. } \\
\text { It would be useful to know the longer term outcome of the } \\
\text { puppies, for example over a few weeks or months. }\end{array}$ \\
\hline
\end{tabular}

De Cramer et al. (2017)

\begin{tabular}{|r|l|}
\hline Population: & $\begin{array}{l}\text { Bitches selected from the general obstetric population as being at } \\
\text { increased obstetric risk. }\end{array}$ \\
\hline Sample size: & $\begin{array}{l}292 \text { caesarean sections in } 256 \text { bitches total. This included } 133 \\
\text { Boerboel, 68 English Bulldog and } 55 \text { other purebred bitches. }\end{array}$ \\
\hline Intervention details: & $\begin{array}{l}\text { In all cases an attempt at unassisted labour was declined by } \\
\text { the owners. }\end{array}$ \\
\hline
\end{tabular}




\begin{tabular}{|c|c|}
\hline & 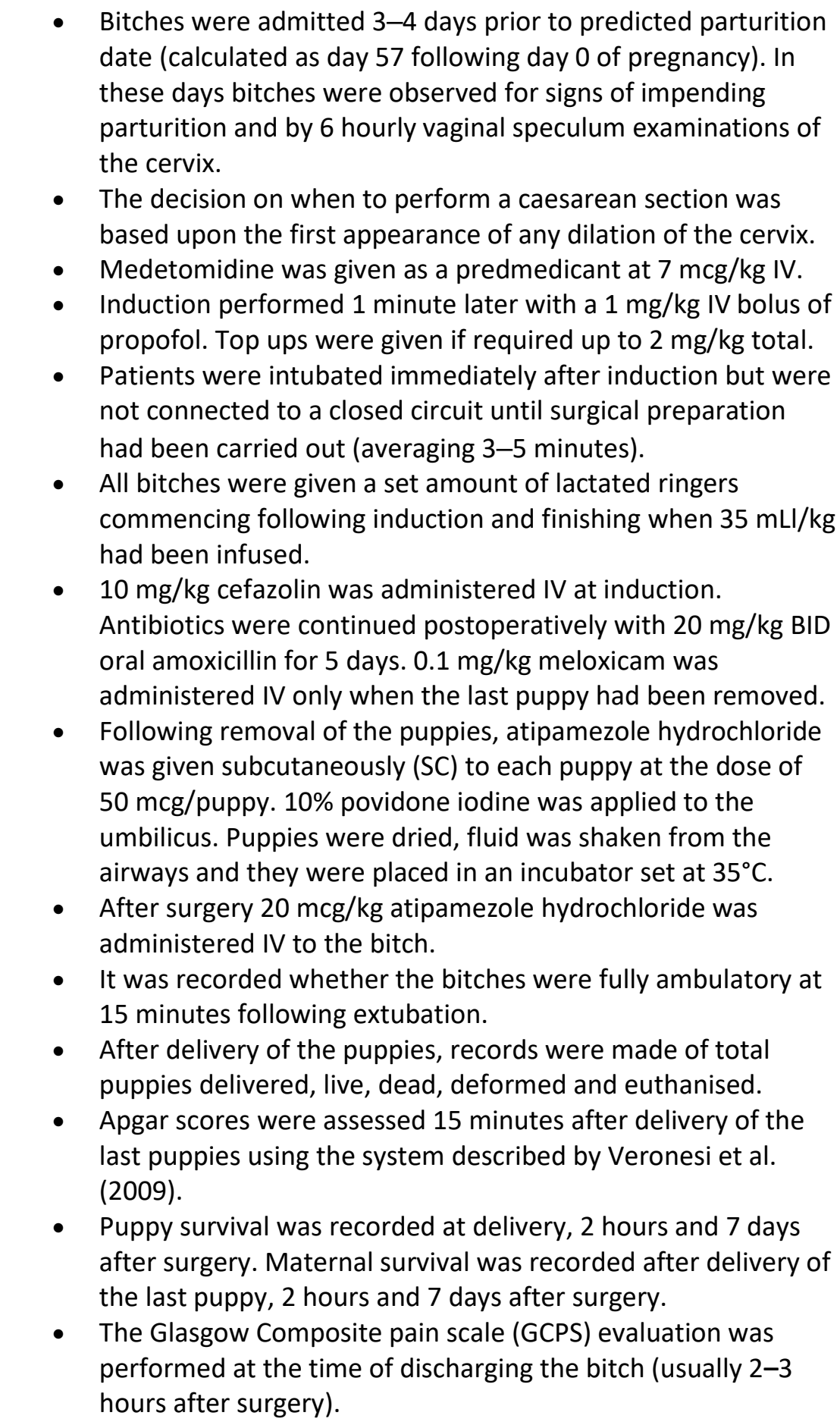 \\
\hline Study design: & Non-comparative, retrospective study \\
\hline Outcome studied: & $\begin{array}{l}\text { 1. Puppy survival measured as percentage alive at birth, } 2 \text { hours } \\
\text { and } 7 \text { days postoperatively. } \\
\text { 2. Puppy vitality measured using an Apgar scoring system } \\
\text { described by Veronesi et al. (2009). } \\
\text { 3. Variables relating to the bitches including whether they were } \\
\text { ambulatory } 15 \text { minutes after extubation, haematocrit } \\
\text { following surgery and comfort of bitches at discharge using } \\
\text { the Glasgow pain scale evaluation. } \\
\text { 4. Surgical timings including total delivery time, average time to } \\
\text { deliver individual puppies and average surgery time. }\end{array}$ \\
\hline
\end{tabular}




\begin{tabular}{|c|c|}
\hline $\begin{array}{l}\text { Main findings: } \\
\text { (relevant to PICO question): }\end{array}$ & 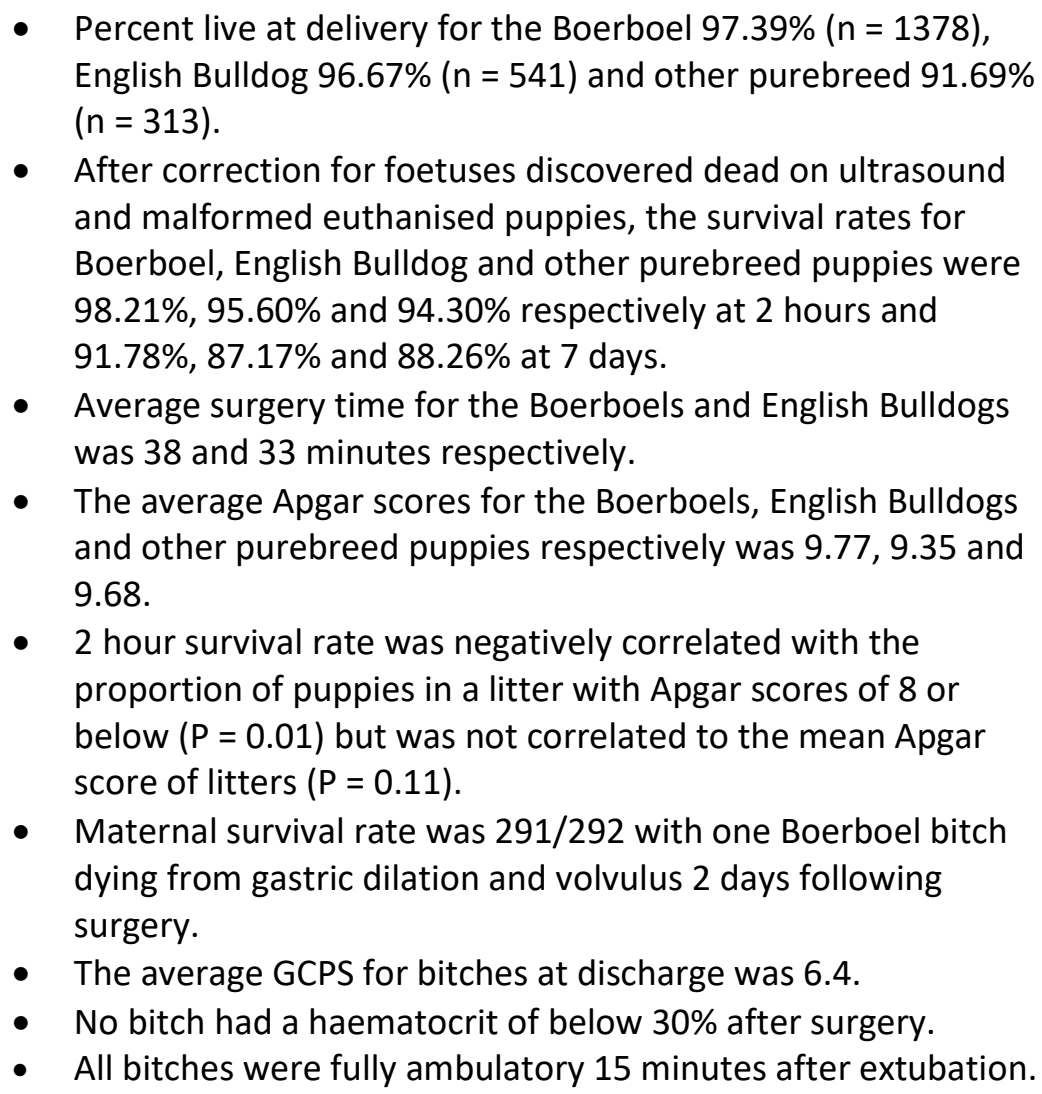 \\
\hline Limitations: & $\begin{array}{l}\text { - Non-comparative study therefore hard to assess how a } \\
\text { different protocol may compare under the same conditions. } \\
\text { - There was little measurement of the safety of anaesthesia for } \\
\text { bitch. Although number of bitches ambulatory at } 15 \text { minutes } \\
\text { gives some indication of recovery, it would be useful to know } \\
\text { intraoperative parameters or to use an anaesthetic scoring } \\
\text { system. } \\
\text { - It could be useful to include GCPS following recovery as well } \\
\text { as at discharge. } \\
\text { - The pain score at discharge is presented as an average score } \\
\text { of all bitches included in the study. This is broad and is not } \\
\text { particularly useful in knowing if bitches who underwent a } \\
\text { more complicated anaesthesia were more painful } \\
\text { postoperatively for example. } \\
\text { - The population in this study was made predominantly of two } \\
\text { breeds which is not representative of the full clinical } \\
\text { population. However, English bulldogs are commonly among } \\
\text { those presenting for caesarean section. } \\
\text { - All caesarean sections in this study were elective and results } \\
\text { may differ to animals undergoing an emergency surgery. } \\
\text { The medetomidine premedication may contribute to changes } \\
\text { in puppy vitality. } \\
\text { Puppies given SC atipamezole prior to Apgar scoring. }\end{array}$ \\
\hline
\end{tabular}




\begin{tabular}{|c|c|}
\hline Population: & Bitches undergoing caesarean section when indicated due to dystocia. \\
\hline Sample size: & $\begin{array}{l}141 \text { bitches - age ranged from } 13 \text { months to } 9 \text { years and represented } \\
60 \text { breeds. } \\
412 \text { puppies. }\end{array}$ \\
\hline Intervention details: & $\begin{array}{l}\text { - The veterinary surgeon on duty determined when caesarean } \\
\text { section was indicated and performed the surgery. In some } \\
\text { cases, puppies had been delivered per vaginum prior to } \\
\text { caesarean section. } \\
\text { - Anaesthesia was induced using propofol given IV to effect. } 6.5 \\
\text { mg/kg was drawn up. Estimated weight of the puppies was } \\
\text { deducted from the bitch's weight before calculating this dose. } \\
20 \text { minutes was allowed to elapse following induction before } \\
\text { delivery of the puppies was begun. } \\
\text { - Patients were immediately intubated and maintained using } \\
\text { gaseous isoflurane (0.5 - 2.0\%) in a mixture of } 65: 35 \\
\text { oxygen:nitrous oxide. } \\
\text { - Immediately after delivery, each puppy's nasal passages, } \\
\text { mouth and pharynx were cleared of mucus. Puppies were also } \\
\text { gently swung to remove fluid. } \\
\text { In some puppies, a combination of crotethamide and } \\
\text { cropropamide were given orally ( } 2 \text { - } 12 \text { mg of each drug). } \\
\text { Viability of puppies were monitored during a period of 1-3 } \\
\text { hours until bitches and puppies were discharged. } \\
\text { Postoperative condition of the bitches and puppies were } \\
\text { determined by telephone interview of owners } 3 \text { months after } \\
\text { caesarean section. }\end{array}$ \\
\hline Study design: & Non-comparative study \\
\hline Outcome studied: & $\begin{array}{l}\text { 1. Status of the bitches - during anaesthesia and in recovery, } \\
\text { whether they could care for their puppies postoperatively and } \\
\text { complications encountered. } \\
\text { 2. Puppy survival measured as percentage born alive and } \\
\text { percentage alive after the } 3 \text { month observation period. } \\
\text { 3. Puppy vitality by looking at how many puppies required more } \\
\text { active resuscitation than usual. }\end{array}$ \\
\hline $\begin{array}{l}\text { Main findings: } \\
\text { (relevant to PICO question): }\end{array}$ & $\begin{array}{l}\text { Bitches } \\
\text { - Induction and maintenance of anaesthesia was uneventful in } \\
\text { all bitches. } \\
\text { Bitches recovered quickly from anaesthesia and without } \\
\text { excitation. } \\
\text { - } 101 / 141 \text { of the bitches were considered by the owners to be } \\
\text { alert and were unaffected by the anaesthesia. The other } 40 \\
\text { were lethargic for } 1-2 \text { days after surgery. } \\
\text { - One brachycephalic bitch developed dyspnoea after surgery } \\
\text { and a tracheotomy was performed following extubation. It } \\
\text { subsequently recovered. } \\
\text { - One bitch had aggressive behaviour toward her puppies and } \\
\text { was unwilling to care for them for } 2 \text { days after surgery. She }\end{array}$ \\
\hline
\end{tabular}




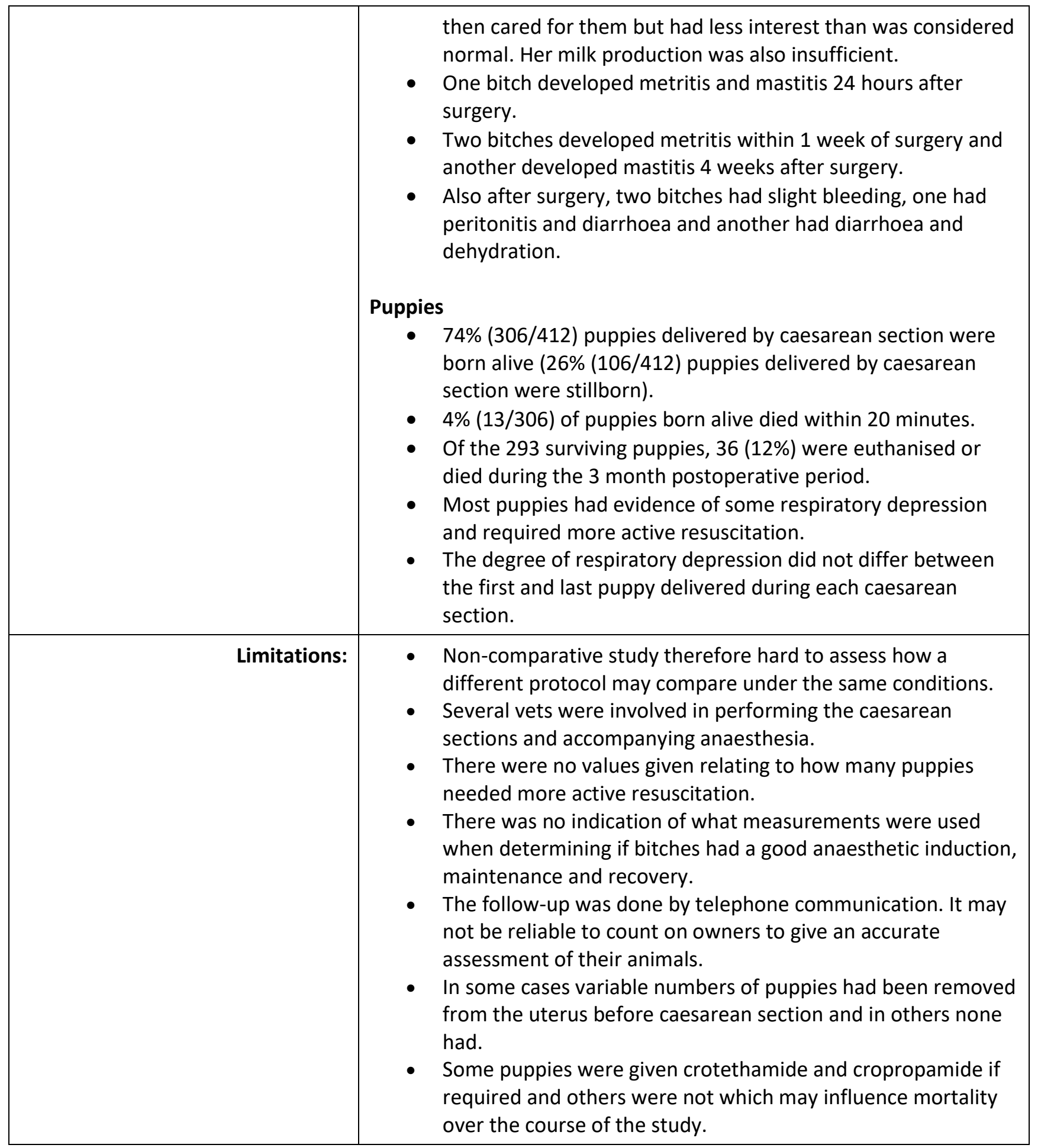

\begin{tabular}{|c|c|}
\hline \multicolumn{2}{|l|}{ Luna et al. (2004) } \\
\hline Population: & $\begin{array}{l}\text { Healthy 2-5 year old bitches requiring caesarean section due to lack } \\
\text { of uterine contractions or inadequate vaginal dilation. Bitches } \\
\text { weighed between } 7 \text { and } 14 \mathrm{~kg} \text {. }\end{array}$ \\
\hline Sample size: & 24 bitches \\
\hline Intervention details: & $\begin{array}{l}\text { Bitches divided into four groups: } \\
\text { 1. Group } 1 \text { - Thiopentone }(8 \mathrm{mg} / \mathrm{kg}) \text { induction }(\mathrm{n}=6)\end{array}$ \\
\hline
\end{tabular}




\begin{tabular}{|c|c|}
\hline & $\begin{array}{l}\text { 2. Group } 2-\text { Midazolam }(0.5 \mathrm{mg} / \mathrm{kg})+\text { ketamine }(2 \mathrm{mg} / \mathrm{kg}) \\
\text { induction ( } \mathrm{n}=6) \\
\text { 3. Group } 3 \text { - Propofol }(5 \mathrm{mg} / \mathrm{kg}) \text { induction }(\mathrm{n}=6) \\
\text { 4. Group } 4 \text { - Lidocaine with adrenaline } 2 \%(2.5 \mathrm{mg} / \mathrm{kg})+ \\
\text { bupivicaine with adrenaline } 0.5 \%(0.625 \mathrm{mg} / \mathrm{kg}) \text { epidural }(\mathrm{n}= \\
\text { 6) } \\
\text { Experimental details: } \\
\text { - } \text { All bitches sedated with } 0.5 \mathrm{mg} / \mathrm{kg} \text { chlorpromazine IV. } \\
\text { - Groups } 1-3 \text { were given their induction and then immediately } \\
\text { intubated and given gaseous enflurane maintenance } \\
\text { anaesthesia. } \\
\text { - Group } 4 \text { underwent epidural anaesthesia at the lumbosacral } \\
\text { space and were not intubated. } \\
\text { 10 mL/kg/hr lactated Ringer's solution infused into all bitches } \\
\text { during the anaesthetic. } \\
\text { Equal numbers of each group were operated on by one of two } \\
\text { experienced veterinary surgeons. } \\
\text { Following removal from the uterus, the airways of the } \\
\text { neonates were cleared and the following measurements were } \\
\text { recorded: heart and respiratory rates, rectal temperature and } \\
\text { neurological reflexes (including pain reflex, suction reflex, } \\
\text { anogenital reflex, magnum reflex and flexion reflex). } \\
\text { The puppies were examined } 7 \text { days later and the numbers } \\
\text { which had died were recorded. }\end{array}$ \\
\hline Study design: & Non-blinded randomised controlled trial \\
\hline Outcome studied: & $\begin{array}{l}\text { 1. Puppy vitality measured using various parameters including } \\
\text { heart and respiratory rate, temperature, and presence or } \\
\text { absence of the reflexes mentioned above. } \\
\text { 2. Puppy mortality. }\end{array}$ \\
\hline $\begin{array}{l}\text { Main findings: } \\
\text { (relevant to PICO question): }\end{array}$ & $\begin{array}{l}\text { The only group relevant to this evidence summary is the propofol } \\
\text { induction group and are therefore the only results included here. The } \\
\text { following was found in this group: } \\
\text { - Mean values for heart and respiratory rate of the puppies } \\
\text { were } 123 \text { beats/minute and } 16 \text { breaths/minute respectively. } \\
\text { - Mortality was } 1 / 24 \text { puppies ( } 4 \% \text { ). } \\
\text { - The percentage of puppies testing positive for each of the } \\
\text { reflexes tested was as follows: } \\
\circ \text { Pain - } 96 \% \\
\circ \text { Suction }-88 \% \\
\circ \text { Anogenital - } 88 \% \\
\circ \text { Magnum }-58 \% \\
\circ \text { Flexion }-46 \%\end{array}$ \\
\hline Limitations: & $\begin{array}{l}\text { - Not blinded. } \\
\text { - The epidural group does not utilise inhalational anaesthesia, } \\
\text { - Narrow weight range of dogs (7-14 kg) may not be } \\
\text { representative of a clinical population. } \\
\text { - Small sample sizes for each group. } \\
\text { - Cases were divided between two veterinary surgeons. }\end{array}$ \\
\hline
\end{tabular}




\begin{tabular}{|l|l|}
\hline However, cases in each group were divided equally and each \\
veterinary surgeon was described as experienced. \\
Although the paper was primarily focused on the effects on \\
the puppies, it may have been useful to record parameters in \\
the bitches to better evaluate the safety of the protocols on \\
them too. \\
- No follow-up of puppy vitality/mortality following the initial \\
measurements.
\end{tabular}

\section{Appraisal, application and reflection}

I found six studies involving the use of alfaxalone or propofol inductions that were relevant to this question (Metcalfe et al., 2014; Doebeli et al., 2013; Vilar et al., 2018; Luna et al., 2004; De Cramer et al., 2017; and Funkquist et al., 1997), two of which were randomised controlled trials which directly compared propofol and alfaxalone inductions (Metcalfe et al., 2014; and Doebeli et al., 2013). These two studies looked to measure similar variables (maternal anaesthetic quality, neonatal mortality and neonatal vitality), but used different methods to determine them. This will be discussed under the headings relating to maternal safety and puppy safety below. These two studies offer the highest quality evidence relevant to my question due to the direct comparison of the two anaesthetic agents.

The other four studies included two randomised controlled trials (Vilar et al., 2018; and Luna et al., 2004) which included a propofol induction as one of the experimental groups, and two non-comparative studies (De Cramer et al., 2017; and Funkquist et al., 1997) in which the anaesthetic protocol included a propofol induction. These studies recorded measures of maternal and puppy mortality and vitality which may be comparable to the two studies including the use of alfaxalone.

One variable which may make it difficult to compare results between studies is the range of anaesthetic and surgical protocols used. Three studies included a premedication in their anaesthetic protocol - chlorpromazine (Luna et al., 2004), medetomidine (De Cramer et al., 2017) and morphine (Vilar et al., 2018). As we have previously established, any anaesthetic agent will have a varying effect on the bitch as well as pass across the placenta and affect neonatal function. Therefore, drawing comparisons between these three studies and the three which do not involve the use of a premedication (Metcalfe et al., 2014; Doebeli et al., 2013; and Funkquist et al., 1997) may be unreliable. Despite this, in a clinical environment many choose to use a premedication in their anaesthetic protocols for caesarean sections therefore these studies are useful to draw conclusions from.

Safety of anaesthesia can be defined in many different ways and in the case of caesarean sections, relates to both the bitches and the puppies individually; I will therefore consider each of these in turn.

\section{Maternal Safety}

With regards to the bitches, perioperative mortality is one potential measure of safety. However, there was a single bitch mortality in only one of the studies (De Cramer et al., 2017), which was a gastric dilation 2 days postoperatively, likely unrelated to the anaesthesia. The relatively small sample sizes used by most of the studies make it difficult to assess differences in mortality between a propofol and alfaxalone induction. In a study by Moon et al. (1998) of 808 bitches undergoing caesarean section, a maternal mortality rate of $1 \%$ $(n=9)$ was found. We can therefore see that differences in mortality may not be apparent with the sample sizes used in these studies. 
Five of the studies attempted in some way to measure the effect of the anaesthetic protocol on the bitches intraoperatively and postoperatively (Metcalfe et al., 2014; Doebeli et al., 2013; Vilar et al., 2018; De Cramer et al., 2017; and Funkquist et al., 1997). One study using propofol (Funkquist et al., 1997) subjectively assessed the status of the bitches, reporting induction and maintenance of anaesthesia to be uneventful in all cases. They also found that 101/141 of the bitches were considered by the owners to be alert and unaffected by the anaesthesia in the 1-2 days following surgery. One brachycephalic bitch developed dyspnoea postoperatively which may be related to the anaesthetic protocol, however this probably falls in line with the expected anaesthetic risks in brachycephalic dogs (Gaynor et al., 1999). Low numbers of other postoperative complications were seen in this study, all of which were unlikely to be related to the anaesthesia. Three studies recorded objective variables pre, intra or postoperatively. De Cramer et al. (2017), one of the propofol studies, found a maternal survival rate of 291/292, with the death due to a gastric dilation and volvulus 2 days postoperatively which is unlikely to be related to the anaesthesia. All bitches were ambulatory 15 minutes after extubation and no bitches had a haematocrit below $30 \%$ following the surgery. Average pain score at discharge was 6.4 which is on the boundary of requiring further pain relief but is probably to be expected following abdominal surgery. Vilar et al. (2018), one of the propofol studies, recorded heart rate, respiratory rate, oxygen saturation, rectal temperature, consciousness, ability to get up and/or walk and accept the puppies. Only results for heart rate, respiratory rate, oxygen saturation and rectal temperature were reported and there were no adverse findings. In the comparison study by Doebeli et al. (2013) temperature, heart rate, respiratory rate, PCV, total protein, anaesthesia duration, mean blood pressure and delivery time were recorded. No differences were found between the propofol and the alfaxalone group. Although reporting objective variables such as in these three studies is useful, I believe an anaesthetic scoring system such as that used in the study by Metcalfe et al. (2014) to be much more useful at deciding the quality of anaesthesia undergone by the patient. The scoring system in this study was described by Ko et al. (1998). They found that of bitches in the alfaxalone group, 47 (98\%), 39 (81\%) and 35 (73\%) scored a top score for induction, anaesthetic effectiveness and recovery respectively. For the same parameters with propofol, 23 (88\%), 17 (65\%) and 18 (69\%) scored top scores, lower in every category when compared to the alfaxalone group. Also in this study, induction apnoea was recorded in $15 \%$ of bitches in the alfaxalone group compared to $25 \%$ of bitches in the propofol group. Maintenance apnoea was recorded in $4 \%$ of bitches in the alfaxalone group compared to $17 \%$ of bitches in the propofol group. Although these values differ, the sample sizes may be too low to draw meaningful conclusions.

From these studies, very few anaesthetic complications were encountered, highlighting that with regards to the bitches, both propofol and alfaxalone are relatively safe to use. This is the conclusion found by the two randomised controlled trials (Metcalfe et al., 2014; and Doebeli et al., 2013) which are the most reliable studies to consider when answering this question. The only real differences between the two induction agents was found by Metcalfe et al. (2014), with the anaesthetic scoring system suggesting that patients induced using alfaxalone may have a slightly better quality of anaesthesia than those induced using propofol. The differences in the numbers of bitches experiencing apnoea in each of the groups may be relevant as both alfaxalone and propofol can cause respiratory depression. However, we probably can't draw conclusions about this from this study alone so further investigation with larger sample sizes may be required to see if apnoea is more apparent using either induction agent.

\section{Puppy Safety}

All six studies looked at two major variables when assessing safety of the anaesthesia relating to the puppies puppy survival, which is directly comparable between studies, and puppy vitality, which each study assessed in different ways. In the four studies including a propofol but not an alfaxalone experimental group (Vilar et al., 2018; Luna et al., 2004; De Cramer et al., 2017; and Funkquist et al., 1997), puppy mortality can likely be compared to that found in the alfaxalone groups in the two comparative studies (Metcalfe et al., 2014; Doebeli et al., 2013) as it was measured as percentage mortality in all studies. With regards to puppy vitality, in most studies one of two measures was used: Apgar scoring or presence of reflexes, both of which can be compared. 
The two randomised controlled trials (Metcalfe et al., 2014; and Doebeli et al., 2013) found no significant difference in the puppy survival between the alfaxalone and propofol groups at birth ( $93 \%$ vs $94 \%$ respectively; $P=0.7$ ) or at 24 hours after ( $89 \%$ vs $89 \%$ respectively; $P=0.9$ ). In light of the strength of evidence of the other papers, these studies are more reliable, indicating that alfaxalone and propofol probably have similar effects regarding puppy mortality. Perioperative puppy mortality in the propofol groups of the other studies ranged from 1.79-28.9\% (Vilar et al., 2018; Luna et al., 2004; De Cramer et al., 2017; and Funkquist et al., 1997). One study (Funkquist et al., 1997) found a much higher puppy mortality rate than in any of the others and when discounting this study puppy mortality would range from $1.79-5.7 \%$. Therefore, puppy mortalities when undergoing a propofol induction fell within acceptable limits for a majority of the studies evaluated. Nevertheless, it is difficult to use these values in context when comparing the two induction agents due to large differences in study protocols and populations. We are therefore best drawing conclusions from the two randomised controlled trials directly comparing alfaxalone and propofol, which found that both agents perform similarly with regards to puppy mortality perioperatively.

Puppy vitality is harder to quantify and compare between groups. Metcalfe et al. (2014) recorded the reflexes that each puppy showed following delivery and found that a greater percentage of alfaxalone group puppies were positive for all four health vigour assessments compared with the propofol group. Luna et al. (2004) recorded similar reflexes and found slightly higher percentages in their propofol group compared to the propofol group in the study by Metcalfe et al. (2014). Doebeli et al. (2013) measured Apgar scores of puppies at 5, 15 and 60 minutes after delivery and found significantly higher scores at all times in the alfaxalone group compared with the propofol group. Vilar et al. (2018) found a higher Apgar score in their propofol and sevoflurane group which was more comparable with the alfaxalone group in the study by Doebeli et al. (2013). However, they used a morphine premedication which reduced the dose of propofol used in some cases which may explain this difference. De Cramer et al. (2017) recorded very high Apgar scores in their cases. This could be due in part to their anaesthetic protocol in which they used a medetomidine premedication and comparably low doses of propofol. As well as this, puppies were given atipamezole following removal, prior to Apgar scoring.

\section{Conclusion}

Taking all studies into account, puppy mortality was generally in accepted proportions and there were few examples of bitch mortality and anaesthetic complications. As there were six studies involving the use of a propofol induction (Metcalfe et al., 2014; Doebeli et al., 2013; Vilar et al., 2018; Luna et al., 2004; De Cramer et al., 2017; and Funkquist et al., 1997) and only two involving the use of an alfaxalone induction (Metcalfe et al., 2014; and Doebeli et al., 2013), we can be more certain that propofol is safe for this purpose. However, current evidence suggests that alfaxalone is a safe alternative and further research with regards to its use will increase certainty of this.

The most reliable studies from those I found, the two randomised controlled trials (Metcalfe et al., 2014; and Doebeli et al., 2013), suggested that there may be small differences between the safety of alfaxalone and propofol inductions in bitches undergoing caesarean section, both for the bitches and the puppies. There is evidence to suggest that alfaxalone may provide a slightly better quality of anaesthesia for the bitches, although only one study supported this (Metcalfe et al., 2014). With regards to the puppies, no significant differences in mortality was observed. Doebeli et al. (2013) found significantly higher Apgar scores in the alfaxalone group compared to the propofol group in the first 60 minutes of life. Metcalfe et al. (2014) found a greater percentage of puppies in the alfaxalone group were positive for each of the reflexes tested, however this was not statistically significant. Therefore there is some evidence that alfaxalone may also be associated with increased neonatal viability in the first 60 minutes following parturition, however further investigation would help to clarify this. 
Both alfaxalone and propofol inductions appear to be relatively safe in the anaesthesia of bitches undergoing caesarean section, suggesting that the current widespread use of propofol is acceptable. However, there is evidence to suggest that alfaxalone may provide bitches with a safer anaesthetic period, and puppies may be delivered with higher indicators of puppy vitality following its use. Further research with regards to the use of alfaxalone for this purpose would be useful to further support this evidence in order to provide the best clinical advice for patients undergoing caesarean section.

\section{Methodology Section}

\begin{tabular}{|c|c|}
\hline \multicolumn{2}{|l|}{ Search Strategy } \\
\hline $\begin{array}{r}\text { Databases searched and dates } \\
\text { covered: }\end{array}$ & $\begin{array}{l}\text { CAB Abstracts on OVID Platform } 1973 \text { - Week } 452019 \\
\text { PubMed 1973 - } 2019 \\
\text { Web of Science } 1973-2019\end{array}$ \\
\hline Search terms: & 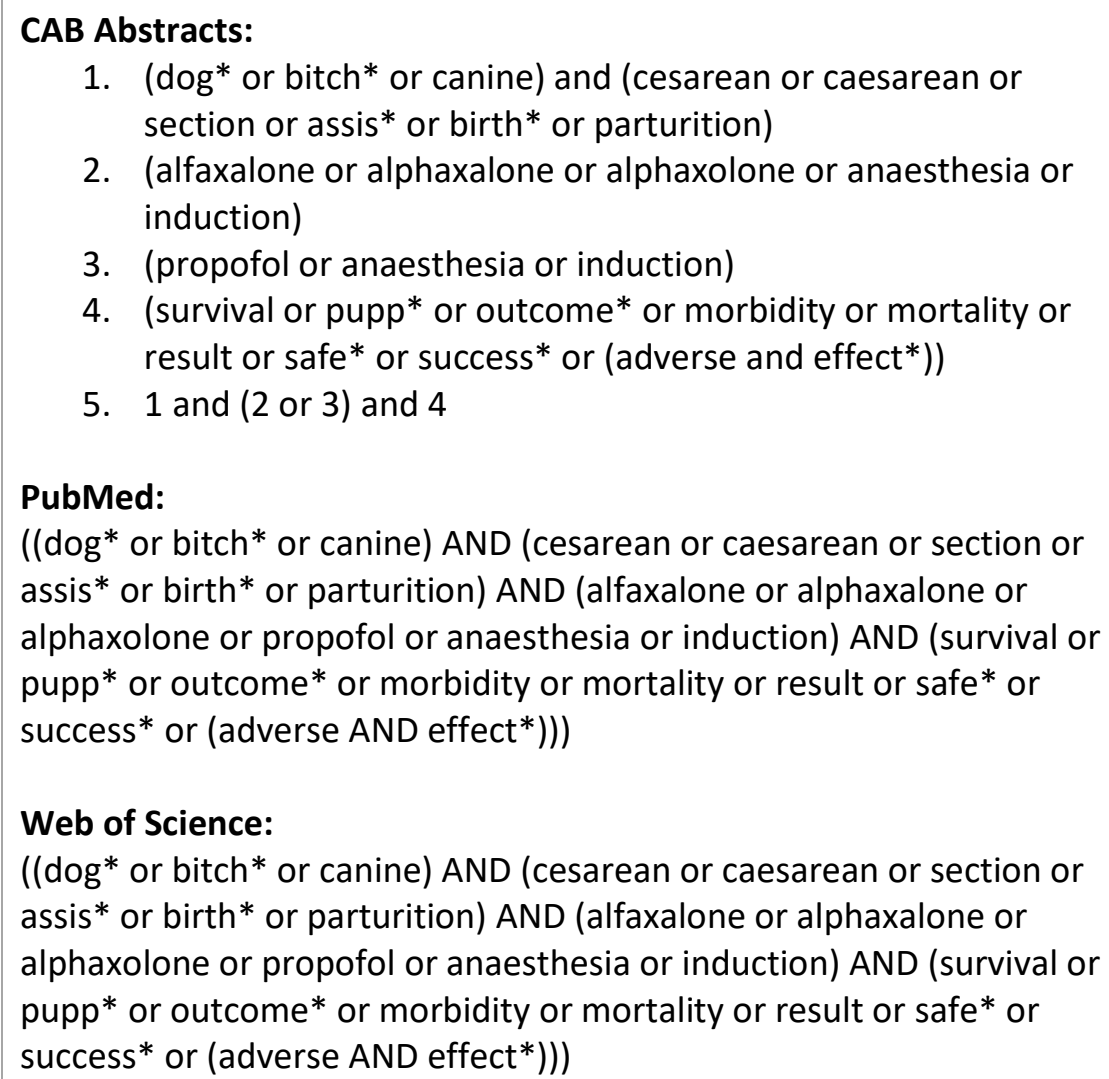 \\
\hline Dates searches performed: & 15 Nov 2021 \\
\hline
\end{tabular}




\section{Exclusion / Inclusion Criteria}

I chose to exclude studies not using gaseous maintenence anaesthesia as anaesthetic protocols such as total intravenous anaesthesia or including epidural analgesia may have a more profound difference in outcomes. By including studies looking at propofol or alfaxalone induction individually as well as comparing the two, I hope to obtain more relevant papers which I can then compare myself at the point of analysis.

\begin{tabular}{|l|l|}
\hline Exclusion: & No full text available \\
& Not relevant to PICO \\
& Non-English language publications \\
& The use of epidural analgesia, co-induction or total intravenous \\
anaesthesia & Effect on puppies not recorded \\
& Single case studies \\
& Published more than 25 years ago \\
& Papers relevant to human medicine \\
\hline Inclusion: & $\begin{array}{l}\text { Studies including propofol or alfaxalone induction either individually } \\
\text { or comparing the two } \\
\text { Studies maintaining animals on gaseous anaesthesia } \\
\text { English language papers relevant to PICO } \\
\text { Full text available } \\
\text { Papers relevant to veterinary medicine }\end{array}$ \\
\hline
\end{tabular}




\begin{tabular}{|c|c|c|c|c|c|c|c|c|}
\hline \multicolumn{9}{|c|}{ Search Outcome } \\
\hline Database & $\begin{array}{l}\text { Number of } \\
\text { results }\end{array}$ & $\begin{array}{l}\text { Excluded - Not } \\
\text { relevant to PICO }\end{array}$ & $\begin{array}{l}\text { Excluded - } \\
\text { Inaccessible }\end{array}$ & $\begin{array}{l}\text { Excluded - } \\
\text { Single case } \\
\text { studies }\end{array}$ & $\begin{array}{l}\text { Excluded - Non-English } \\
\text { language publications }\end{array}$ & $\begin{array}{c}\text { Excluded - Published } \\
\text { more than } 25 \text { years } \\
\text { ago }\end{array}$ & $\begin{array}{l}\text { Excluded - } \\
\text { Duplication }\end{array}$ & $\begin{array}{l}\text { Total } \\
\text { relevant } \\
\text { papers }\end{array}$ \\
\hline $\begin{array}{l}\text { CAB } \\
\text { Abstracts }\end{array}$ & 174 & 156 & 2 & 1 & 6 & 1 & 2 & 6 \\
\hline PubMed & 485 & 478 & 0 & 0 & 1 & 0 & 0 & 6 \\
\hline $\begin{array}{l}\text { Web of } \\
\text { Science }\end{array}$ & 241 & 234 & 0 & 0 & 1 & 0 & 0 & 6 \\
\hline \multicolumn{8}{|c|}{ Total relevant papers } & 6 \\
\hline
\end{tabular}

Veterinary Evidence

ISSN:2396-9776

Vol 5, Issue 3

DOI: http://dx.doi.org/10.18849/ve.v3i1.129

next review date: 15 Nov 2021 
The author declares no conflicts of interest.

\section{REFERENCES}

1. Batista, M., Moreno, C., Vilar, J., Golding, M., Brito, C., Santana, M. and Alamo, D. (2014). Neonatal viability evaluation by Apgar score in puppies delivered by cesarean section in two brachycephalic breeds (English and French bulldog). Animal Reproduction Science, 146(3-4):218-226.

DOI: https://doi.org/10.1016/i.anireprosci.2014.03.003

2. De Cramer, K.G.M., Joubert, K.E. and Nöthling, J.O. (2017). Puppy survival and vigor associated with the use of low dose medetomidine premedication, propofol induction and maintenance of anesthesia using sevoflurane gas-inhalation for cesarean section in the bitch. Theriogenology, 96:10-15. DOI: https://doi.org/10.1016/i.theriogenology.2017.03.021

3. Doebeli, A., Michel, E., Bettschart, R., Hartnack, S. and Reichler, I.M. (2013). Apgar score after induction of anesthesia for canine cesarean section with alfaxalone versus propofol. Theriogenology, 80(8):850-854. DOI: https://doi.org/10.1016/i.theriogenology.2013.07.006

4. Funkquist, P.M., Nyman, G.C., Löfgren, A.J. and Fahlbrink, E.M. (1997). Use of propofol-isoflurane as an anesthetic regimen for cesarean section in dogs. Journal of the American Veterinary Medical Association, 211(3):313-317.

5. Gaynor, J.S., Dunlop, C.I., Wagner, A.E., Wertz, E.M., Golden, A.E. and Demme, W.C. (1999). Complications and mortality associated with anesthesia in dogs and cats. Journal of the American Animal Hospital Association, 35(1):13-17. DOI: https://doi.org/10.5326/15473317-35-1-13

6. Ko, J.C., Nicklin, C.F., Melendaz, M., Hamilton, P. and Kuonen, C.D. (1998). Effects of a microdose of medetomidine on diazepam-ketamine induced anesthesia in dogs. Journal of the American Veterinary Medical Association, 213(2):215-219.

7. Luna, S.P.L., Cassu, R.N., Castro, G.B., Neto, F.T., Silva, J.R. and Lopes, M.D., 2004. Effects of four anaesthetic protocols on the neurological and cardiorespiratory variables of puppies born by caesarean section. Veterinary Record, 154(13), pp.387-389.

DOI: http://dx.doi.org/10.1136/vr.154.13.387

8. Metcalfe, S., Hulands-Nave, A., Bell, M., Kidd, C., Pasloske, K., O'hagan, B., Perkins, N. and Whittem, T. (2014). Multicentre, randomised clinical trial evaluating the efficacy and safety of alfaxalone administered to bitches for induction of anaesthesia prior to caesarean section. Australian Veterinary Journal, 92(9):333-338. DOI: https://doi.org/10.1111/avj.12223

9. Moon, P.F., Erb, H.N., Ludders, J.W., Gleed, R.D. and Pascoe, P.J. (1998). Perioperative management and mortality rates of dogs undergoing cesarean section in the United States and Canada. Journal of the American Veterinary Medical Association, 213(3):365-369.

10. Sánchez-Alcaraz, A., Quintana, M.B. and Laguarda, M. (1998). Placental transfer and neonatal effects of propofol in caesarean section. Journal of Clinical Pharmacy and Therapeutics, 23(1):19-23. DOI: https://doi.org/10.1046/j.1365-2710.1998.00124.x

11. Silva, L.C.G., Lucio, C.F., Veiga, G.A.L., Rodrigues, J.A. and Vannucchi, C.I. (2009). Neonatal clinical evaluation, blood gas and radiographic assessment after normal birth, vaginal dystocia or caesarean section in dogs. Reproduction in Domestic Animals, 44:160-163. DOI: https://doi.org/10.1111/j.14390531.2009.01392.x

12. Veronesi, M.C., Panzani, S., Faustini, M. and Rota, A. (2009). An Apgar scoring system for routine assessment of newborn puppy viability and short-term survival prognosis. Theriogenology, 72(3):401407. DOI: https://doi.org/10.1016/i.theriogenology.2009.03.010 
13. Vilar, J.M., Batista, M., Pérez, R., Zagorskaia, A., Jouanisson, E., Díaz-Bertrana, L. and Rosales, S. (2018). Comparison of 3 anesthetic protocols for the elective cesarean-section in the dog: Effects on the bitch and the newborn puppies. Animal Reproduction Science, 190:53-62.

DOI: https://doi.org/10.1016/i.anireprosci.2018.01.007 


\section{EVIIDEFeE

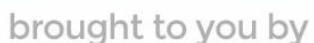 \\ RCVS KNOWLEDGE}

\section{Intellectual Property Rights}

Authors of Knowledge Summaries submitted to RCVS Knowledge for publication will retain copyright in their work, and will be required to grant RCVS Knowledge a non-exclusive license of the rights of copyright in the materials including but not limited to the right to publish, re-

publish, transmit, sell, distribute and otherwise use the materials in all languages and all media throughout the world, and to license or permit others to do so.

\section{Disclaimer}

Knowledge Summaries are a peer-reviewed article type which aims to answer a clinical question based on the best available current evidence. It does not override the responsibility

of the practitioner. Informed decisions should be made by considering such factors as individual clinical expertise and judgement along with patient's circumstances and owners' values. Knowledge Summaries are a resource to help inform and any opinions expressed within the Knowledge Summaries are the author's own and do not necessarily reflect the view of the RCVS Knowledge. Authors are responsible for the accuracy of the content. While the

Editor and Publisher believe that all content herein are in accord with current recommendations and practice at the time of publication, they accept no legal responsibility

for any errors or omissions, and make no warranty, express or implied, with respect to material contained within.

For further information please refer to our Terms of Use.

RCVS Knowledge is the independent charity associated with the Royal College of Veterinary Surgeons (RCVS). Our ambition is to become a global intermediary for evidence based veterinary knowledge by providing access to information

that is of immediate value to practicing veterinary professionals and directly contributes to evidence based clinical decision-making.

https://www.veterinaryevidence.org/

RCVS Knowledge is a registered Charity No. 230886.

Registered as a Company limited by guarantee in England and Wales No. 598443.

Registered Office: Belgravia House, 62-64 Horseferry Road, London SW1P 2AF

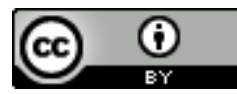

This work is licensed under a Creative Commons Attribution 4.0 International License. 